Potravinarstvo Slovak Journal of Food Sciences vol. 15, 2021, p. 101-110

https://doi.org/10.5219/1445

Received: 9 August 2020. Accepted: 2 January 2021.

Available online: 28 February 2021 at www.potravinarstvo.com

(C) 2021 Potravinarstvo Slovak Journal of Food Sciences, License: CC BY 4.0

ISSN 1337-0960 (online)

\title{
THE EFFECT OF KEFIR-SPIRULINA ON GLYCEMIC STATUS AND ANTIOXIDANT ACTIVITY IN HYPERGLYCEMIA RATS
}

\author{
Nur Laela, Anang Mohamad Legowo, Faizah Fulyani
}

\begin{abstract}
Diabetes mellitus (DM) is a metabolic disorder characterized by chronic hyperglycemia. It is caused by impaired insulin secretion or by insulin receptor insensitivity. DM and its complications are often related to increases in the level of oxidative stress. Spirulina is a nutrient-dense food that contains an abundance of antioxidant compounds. In combination with kefir, it may serve as both a nutrient-rich diet and an antioxidant agent that can prevent complications of diabetes. This study aims to investigate the nutritional content of kefir-spirulina and its effect on glycemic status and antioxidant activity in streptozotocin-nicotinamide (STZ-NA) induced diabetic rats. A total of 30 male Sprague Dawley rats were divided into five groups: normal control (K1), diabetic control (K2), pioglitazone treatment (K3), kefir combined with $1 \%$ spirulina treatment (P1), and kefir combined with $2 \%$ spirulina treatment (P2). All rats were induced by STZ-NA, except for the normal control. Before and after the 28 days of intervention, blood samples were taken and analyzed for fasting plasma glucose, postprandial glucose, and SOD activity. The nutritional content, ethanol content, and total antioxidant capacity of kefir-spirulina were also analyzed. The diabetic rats that were fed with kefir-spirulina (P1 and P2) had a significant decrease in both fasting and postprandial plasma glucose $(p<0.001)$ compared to the diabetic control rats. The decrease of plasma glucose in $\mathrm{K} 2$ is comparable to the control rats treated with the diabetic drug pioglitazone (K3). The activity of SOD in diabetic rats fed in P1 and P2 were higher $(p<0.001)$ than in untreated diabetic rats $(\mathrm{K} 2)$. The IC50 of kefirspirulina was $42-43 \mathrm{ppm}$. It was concluded that kefir combined with spirulina has high nutrition and antioxidant capacity, which is proven to be capable of controlling glycemic status and enhancing antioxidant status in a diabetic rat model.
\end{abstract}

Keywords: kefir; spirulina; antioxidant; hyperglycemia; SOD

\section{INTRODUCTION}

Diabetes mellitus (DM) is a metabolic disorder characterized by chronic hyperglycemia, impaired insulin secretion, insulin resistance, and $\beta$ cell dysfunction. The common characteristic symptoms include thirst, polyuria, polyphagia, blurring of vision, and weight loss (WHO, 1999). The International Diabetic Federation (IDF) reported that approximately 451 million individuals suffered from DM in 2017, and this number is predicted to increase to 693 million in 2045 (Cho et al., 2018). The mortality rate in 2017 of individuals aged $20-99$ was 5 million, and this figure will continue to increase worldwide, creating a global health burden.

Hyperglycemia induces free radicals production and defects in the endogenous antioxidant defense mechanism, resulting in oxidative stress (Moussa, 2018; Schultz Johansen et al., 2005). Free radicals such as reactive oxygen species (ROS) can be generated through many processes, including glucose auto-oxidation, change of redox balance, reduction of antioxidant concentration, and failure of antioxidant enzyme activity. ROS leads to oxidative damage to various biomolecules in the cell, such as proteins, lipids, and nucleic acids. ROS oxidizes the polyunsaturated fatty acids (PUFA) in the cell membranes and generate hydrogen peroxides. These hydrogen peroxides could undergo fragmentation, creating reactive intermediates, such as prostaglandin, isoprostane, and malondialdehyde (MDA) (Catalá, 2009). The accumulation of ROS could induce macromolecules' glycation and may cause chronic complications in DM such as retinopathy, nephropathy, atherosclerosis, and coronary heart disease (Schultz Johansen et al., 2005; Matough et al., 2012).

The high levels of ROS are commonly accompanied by the impairment of various antioxidant enzymes, such as catalase, glutathione peroxidase (GSH-Px), and superoxide dismutase (SOD) (Moussa, 2018). These enzymes are critical in clearing the free radicals generated in the body. SOD, for example, is an essential antioxidant enzyme capable of preventing damage to macromolecular components of cells and repairing free radical compounds (Valko et al., 2007).

The clinical management of DM controls glycemic status by consuming diabetic drugs either orally or by injection. However, this approach could increase complications such as hyperinsulinemia and infection (Gedawy et al., 2018; 
Santaguida et al., 2005). Limitation in drug treatment encourages an alternative approach to DM management. There has been a growing body of evidence that functional foods and probiotics have beneficial effects on DM management (Venkatakrishnan, Chiu and Wang, 2019). Various foods rich in nutrients and bioactive compounds such as fruits, vegetables, legumes, probiotics, and fermented foods have shown promising results in controlling glycemic status and decreasing oxidative stress (Barengolts et al., 2019; Habib and Parvin, 2008).

Kefir is fermented milk containing approximately 52 types of lactic acid bacteria and yeast (Pogačić et al., 2013). It is widely used as a medication to treat various illnesses in middle Asian countries (Kýlýc et al., 1999). Kefir acts as antioxidants that are capable of enhancing SOD, GSH-Px, and catalase activity (Judiono, Djokomoeljanto and Hadisaputro, 2011).

In this study, we aimed to explore kefir's potential as functional food for controlling glycemic status and antioxidant status in DM modeled rats. To enhance the kefir activity and nutrition, we combined kefir with spirulina, nutrient-rich microalgae. Having high protein content $(60-70 \%)$ (Sadeghi et al., 2018) and various bioactive compounds (Wu et al., 2005), spirulina has shown effectivity in controlling blood glucose (Sadeghi et al., 2018; Senthil, Balu and Murugesan, 2013) and the level of oxidative stress (Niccolai et al., 2019; Layam and Reddy, 2007).

\section{Scientific hypothesis}

This study hypothesizes that a combination of kefir and spirulina could serve as a novel functional food in DM management through controlling glycemic status and antioxidant capacity in a diabetic rat model.

\section{MATERIALS AND METHODOLOGY}

\section{Statement of ethics}

This research obtained ethical approval with Ethical Clearance 152/EC/H/KEPK/FK-UNDIP/XII/2019 Faculty of Medicine, Diponegoro University, Semarang, Indonesia.

\section{Chemicals and reagents}

All the chemicals used were of the highest purity grade. Streptozotocin (STZ) and nicotinamide (NA) were purchased from Nacalai Tesque, Inc. (Kyoto, Japan). Chloric acid, sulphuric acid, potassium sulfate, copper sulfate, ethanol, methanol, demineralized water, potassium hydroxide, and acetone were purchased from Merck. A kit for the glucose assay (GOD-PAP) was procured from DiaSys, Holzheim, Germany. A kit for estimation of SOD activity was procured from BioVision, Inc.

\section{Preparation of kefir-spirulina}

Spirulina was obtained from PT Neoalgae Sukoharjo, Central Java. Spirulina generally contains $60-70 \%$ total protein, including essential amino acids such as leucine, isoleucine and, valine. It has $4-7 \%$ lipids, essential fatty acids such as linoleic and $\gamma$-linolenic acid, and $\omega-3$ and $\omega-6$ polyunsaturated fatty acids. It also contains provitamin A, vitamin B12, and $\beta$-carotene (Koru, 2012).

Kefir-spirulina was made by combining $1 \%$ cow's milk with either $1 \%(\mathrm{w} / \mathrm{v})$ or $2 \%(\mathrm{w} / \mathrm{v})$ spirulina, followed by pasteurization. Kefir grain $(5 \%)$ was added to the solution after it cooled down, followed by incubation at room temperature $\left(25-37^{\circ} \mathrm{C}\right)$ for 24 hours (Figure 1). After separating the grain from the solution, the kefir-spirulina mixture was analyzed for its nutritional content, ethanol content, and antioxidant capacity.

\section{Nutrient analysis}

Nutrient analysis was performed according to the standard official methods of the Association of Official Analytical Chemists procedures 2005 (AOAC, 2005). Nutritional parameters such as moisture, protein, fat, ash, carbohydrate, and fiber were determined.

\section{Moisture content}

Approximately $2 \mathrm{~g}$ of the sample (W1) was placed on a dish and dried in an oven for 5 hours at $95-105{ }^{\circ} \mathrm{C}$. After drying, the dish was transferred to a desiccator to cool, and the sample was subsequently reweighed (W2). The moisture content was calculated as:

$$
\text { Moisture }(\%)=\frac{(\mathrm{W} 1-\mathrm{W} 2)}{\mathrm{W} 1} \times 100 \%
$$

$\mathrm{W} 1$ = weight $(\mathrm{g})$ of the sample before drying, $\mathrm{W} 2$ = weight $(\mathrm{g})$ of the sample after drying.

\section{Ash content}

A drying method was used to assay the ash content. Briefly, $1 \mathrm{~g}$ of the sample was placed in a silica crucible. The sample was spread in an even layer and placed in a muffle furnace. The furnace temperature was allowed to reach a temperature of $550{ }^{\circ} \mathrm{C}$ for approximately 2 hours or until the sample turned white or slightly grey. The ash content was calculated as follows:

$$
\text { Ash }(\%)=\frac{\text { Weight of ash }}{\text { Weight of the sample }} \times 100 \%
$$

\section{Crude fat content}

Fats were determined by the intermittent Soxhlet extraction method. A flask was weighed as an initial weight. A $2 \mathrm{~g}$ sample was placed in the fat sleeve. The sample and $200 \mathrm{~mL}$ of chloroform were added to the Soxhlet flask apparatus. The flask was then placed in an oven at $105{ }^{\circ} \mathrm{C}$ for 2 hours, then cooled in a desiccator. The percent crude fat was determined using the following formula:

$$
\text { Crude Fat }(\%)=\frac{\text { Wt. of ether extract }}{\text { Wt. of sample }} \times 100 \%
$$



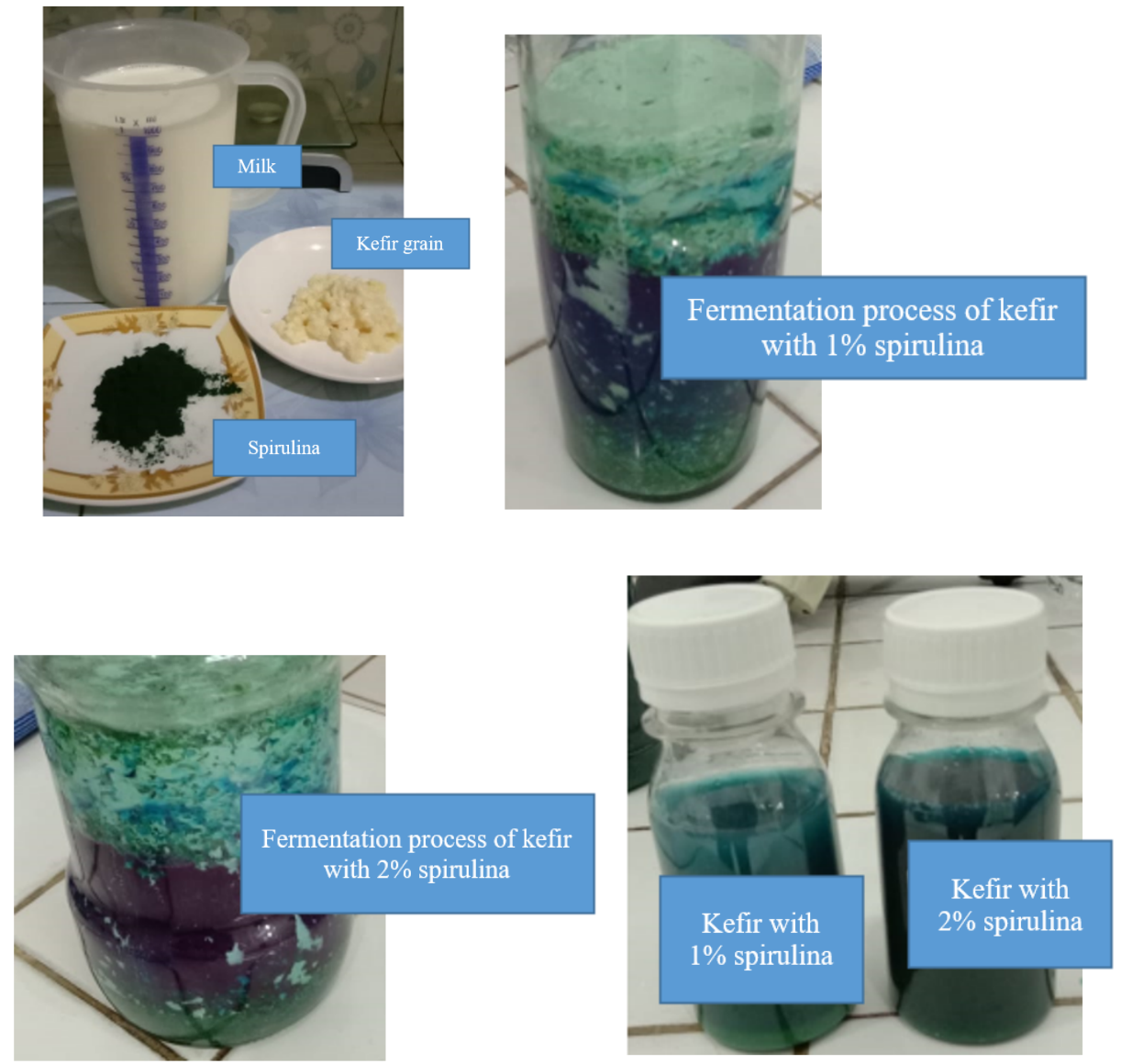

Figure 1 Fermentation process of kefir with $1 \%$ and $2 \%$ of spirulina.

\section{Crude protein content}

Protein content in the sample was determined by the Kjeldahl method according to (Afifah et al., 2019) with some modification. A $2 \mathrm{~g}$ sample was digested by adding $15 \mathrm{~mL}$ of concentrated $\mathrm{H} 2 \mathrm{SO} 4$ and two tablets of catalyst. The solution mixture was boiled until the solution was clear. The solution was filtered into a volumetric flask and connected for distillation. Ammonia was steam distilled from the solution, to which $50 \mathrm{~mL}$ of $45 \%$ sodium hydroxide solution had been added. $150 \mathrm{~mL}$ of the distillate was collected in a flask containing $100 \mathrm{~mL}$ of $0.1 \mathrm{~N} \mathrm{HCl}$ and methyl red indicator. The ammoniacontaining distillate reacted with the acid, and the excess acid in the flask was estimated by back titration against 2.0 $\mathrm{M} \mathrm{NaOH}$.

\section{Carbohydrate}

Total carbohydrate content was calculated as an approximation percentage with the following formula:

(\%) Carbohydrate $=100 \%-[$ Protein $(\%)+$ Moisture (\%) + Ash (\%) + Fat (\%)

\section{Dietary fiber content}

The sample $(2-3 \mathrm{~g})$ was mixed with $50 \mathrm{~mL}$ of $1.25 \%$ $\mathrm{H}_{2} \mathrm{SO}_{4}$ in a flask for 30 minutes. An amount of $50 \mathrm{~mL}$
$\mathrm{NaOH}(3.25 \%)$ was added to the mixture, then boiled. The mixture was filtered through a Buchner funnel containing Whatman paper and washed with $1.25 \% \mathrm{H}_{2} \mathrm{SO}_{4}$, hot water, and $96 \%$ ethanol. The residue left in the Whatman paper was weighed.

$$
\text { Crude fiber }(\%)=\frac{W 1-W 2}{W 1} \times 100 \%
$$

\section{Ethanol content}

The ethanol content in the sample was determined using high-performance liquid chromatography (HPLC), according to (Dias et al., 2020). Water as a mobile phase was used together with column YMC-Triat C8 (150 mm $\times$ $4.6 \mathrm{~mm}$, particle size: $5 \mu \mathrm{m}) .20 \mu \mathrm{L}$ of the sample was run with $1 \mathrm{~mL} \cdot \mathrm{min}^{-1}$ flowrate at $40{ }^{\circ} \mathrm{C}$ for 15 minutes.

\section{Antioxidant activity}

Antioxidant activity was determined based on 2,2-Diphenyl-1-picrylhydrazyl (DPPH) scavenging activity. The kefir sample was diluted in methanol absolute and mixed well. A series of sample concentrations of $5 \mathrm{ppm}, 10 \mathrm{ppm}$, and $20 \mathrm{ppm}$ were diluted with methanol absolute up to $5 \mathrm{~mL}$, after which $1 \mathrm{~mL}$ of $0.4 \mathrm{mM} \mathrm{DPPH}$ solution was added. The mixture was shaken vigorously and incubated at room temperature for $30 \mathrm{~min}$ in the dark, 
and the absorbance was measured at $517 \mathrm{~nm}$. Trolox with various concentrations was used to make a standard curve.

$$
\% \text { Inhibition }=\frac{A_{\text {control }}-A_{\text {sample }}}{A_{\text {control }}} \times 100 \%
$$

The concentration of kefir-spirulina providing 50\% inhibition $\left(\mathrm{IC}_{50}\right)$ was calculated from the plotted graph of kefir-spirulina concentration and percentage of inhibition. The $\mathrm{IC}_{50}$ value was then estimated using the fitted line (Hendel, Larous and Belbey, 2016).

$$
\begin{gathered}
\mathrm{Y}=\mathrm{a} * \mathrm{X}+\mathrm{b} \\
\mathrm{IC}_{50}=\frac{(0.5-b)}{a}
\end{gathered}
$$

\section{Animal experiment}

The sample used in this study was a male Sprague Dawley Rattus novegicus aged 8 weeks, weighing approximately $150-200 \mathrm{~g}$. The animals were acclimatized for one week in a temperature-controlled room $\left(20-25^{\circ} \mathrm{C}\right)$ and maintained on a $12 \mathrm{~h}$ light/12 h dark cycle. They were allowed free access to a standard commercial diet (Comfeed II, Japfa) and tap water. A total of 30 male Sprague Dawley rats were divided into five groups: normal control (K1), diabetic control (K2), pioglitazone treatment (K3), kefir combined with $1 \%$ spirulina treatment (P1), and kefir combined with $2 \%$ spirulina treatment $(\mathrm{P} 2)$. All rats were induced by streptozotocin-nicotinamide (STZ- NA), except for the normal control. Nicotinamide (NA) was dissolved in saline solution and given intraperitoneally (i.p.) at a dose of $110 \mathrm{mg} \cdot \mathrm{kg}^{-1}$ body weight. After 15 minutes, the rats were induced by $45 \mathrm{mg} \cdot \mathrm{kg}^{-1}$ body weight of streptozotocin (STZ) in citrate buffer (i.p.). The rats considered having diabetes if three days after induction the fasting blood glucose was more than $126 \mathrm{mg} \cdot \mathrm{dL}^{-1}$ and plasma glucose were more than $200 \mathrm{mg}$. $\mathrm{dL}^{-1}$. Groups $\mathrm{P} 1$ and $\mathrm{P} 2$ received kefir-spirulina via gavage with a total dose of $3 \mathrm{~mL} .200 \mathrm{~g}^{-1}$ body weight per day orally for 28 days. Group K3 received the diabetes drug pioglitazone at a dose of $0.27 \mathrm{mg} .200 \mathrm{~g}^{-1}$ body weight per day orally for 28 days.

Before and after the 28 days of intervention, blood samples were taken through the retro-orbital sinus and were analyzed for fasting plasma glucose, postprandial glucose, and SOD activity.

\section{Blood glucose test}

Fasting and postprandial blood glucose were determined using the Glucose Oxidase Phenol 4-Aminoantipyrine Peroxidase (GPO-PAP) according to the kit (DiaSys, Holzheim, Germany). Briefly, $10 \mu \mathrm{L}$ of blood plasma was mixed with $1000 \mu \mathrm{L}$ of reagent, then incubated for 20 minutes at $20-25{ }^{\circ} \mathrm{C}$. The absorbance was read at 505 nm (System, 2012).

\section{Analysis of SOD activity}

SOD activity was measured via the WST method using a kit by BioVision. Briefly, $20 \mu \mathrm{L}$ of blood plasma was mixed with $200 \mu \mathrm{L}$ of WST solution, $20 \mu \mathrm{L}$ of dilution buffer, and $20 \mu \mathrm{L}$ of the SOD working solution. The mixture was then incubated for 20 minutes at $37{ }^{\circ} \mathrm{C}$, and absorbance was read at $450 \mathrm{~nm}$ (SOD Assay, 2019).

\section{Statistical analysis}

Statistical analyses were performed using SPSS version 24 (IBM, 2016). The obtained data were analyzed using Shapiro-Wilk since the data were normally distributed. The paired t-test and one-way ANOVA were used to determine the effect of experimental treatments. Differences were considered to be significant if $p$-values less than $0.05(p<0.05)$. In the case of variance homogeneity $p>0.05$, post-hoc LSD was used; otherwise, post-hoc Tamhane was used.

\section{RESULTS AND DISCUSSION Nutrient content}

Table 1 showed the nutrient content of the two formulations of kefir-spirulina. The water content was $93.82 \%$ and $92.67 \%$ for formulas $\mathrm{A}$ and $\mathrm{B}$, respectively. The high water content in the two formulations was due to the clear part of the kefir used in the formulation, while the curd was separated. Our result is in line with several other studies that showed that kefir generally contained 89 - 90\% water (Sarkar, 2007; Plessas et al., 2017).

The ash content for the kefir formulation was similar, at $0.76 \%$ (formula A) and $0.72 \%$ (formula B). Our results were comparable with several other studies that found ash content was around $0.7-1.1 \%$ (Arslan, 2014; Plessas et al., 2017; Rosa et al., 2017).

The two kefir formulations prepared in this study contained $4.02 \%$ and $5.53 \%$ protein, almost twice the minimum amount suggested by CODEX STAN 234-2003 (FAO, 2010). It has been shown previously that kefir usually contains 3\% of protein (Sarkar, 2007; Plessas et al., 2017; Magalhães et al., 2011). The improvement of the protein content of the kefir prepared in this study is likely due to the addition of spirulina, which is rich in protein (circa $60-70 \%$ of its dry weight) (Wu et al., 2005). The addition of $2 \%$ spirulina to the kefir showed higher protein content than the addition of $1 \%$ spirulina.

The carbohydrates content of kefir-spirulina for formula $\mathrm{A}$ and $\mathrm{B}$ were $1.56 \%$ and $1.12 \%$, respectively. These results are lower than previous studies indicating that kefir contains carbohydrates between 3.8\% and 4.7\% (Arslan, 2014). The fiber content in this study's kefir formulations was $2.49 \%$ (formula A) and $6.40 \%$ (formula B). Fiber is a nonstarch polysaccharide with high nutritional value; the high fiber content in spirulina will slow down the glucose absorption in the ileum, thereby lowering postprandial glucose (Hernández-Alonso et al., 2017; Chandalia et al., 2000).

Fat content in the kefir formulations was $1.04 \%$ (formula A) and $0.59 \%$ (formula B). The low level of fat found in our kefir formulations was presumably due to lipase activity, which was produced by lactic acid bacteria (BAL). This study's fat content is relatively higher compared to the $0.2 \%$ that was shown in previous studies (Sarkar, 2007; Plessas et al., 2017). Fat content in the kefir could vary depending on the type of milk used in the fermentation process (Otles and Cagindi, 2003). 
Table 1 The nutritional content of the two formulations of kefir-spirulina.

\begin{tabular}{|c|c|c|c|c|c|c|}
\hline Formulation & Water & Protein & $\begin{array}{l}\text { Fat } \\
(\%)\end{array}$ & Ash & Carbohydrate & Fiber \\
\hline $\begin{array}{l}\text { Kefir with } 1 \% \\
\text { ulina }\end{array}$ & $93.82 \pm 0.17$ & $4.02 \pm 0.22$ & $0.20 \pm 0.05$ & $0.76 \pm 0.04$ & $1.56 \pm 0.22$ & 2.49 \\
\hline $\begin{array}{l}\text { Kefir with } 2 \% \\
\text { ulina }\end{array}$ & $92.67 \pm 0.47$ & $5.53 \pm 0.22$ & $0.29 \pm 0.07$ & $0.72 \pm 0.08$ & $1.12 \pm 1.17$ & 6.40 \\
\hline
\end{tabular}

Table 2 Ethanol content and antioxidant activity of kefir-spirulina.

\begin{tabular}{lcc}
\hline Formulation & Ethanol (\%) & IC $_{\mathbf{5 0}}$ (ppm) \\
\hline (A) Kefir with 1\% spirulina & 0.59 & $43.65 \pm 0.15$ \\
(B) Kefir with 2\% spirulina & 0.65 & $42.00 \pm 0.08$ \\
\hline
\end{tabular}

Table 3 The average body weight of the experimental animals.

\begin{tabular}{lcccc}
\hline \multicolumn{1}{c}{ Group } & \multicolumn{3}{c}{ Body weight (g) \pm SD $^{\boldsymbol{p}^{b}}$} \\
\cline { 2 - 4 } & Pre-treatment & Post-treatment & Delta pre-post \\
\hline K1 (Normal control) & $187.67 \pm 12.59$ & $199.33 \pm 22.28$ & $11.66 \pm 17.68$ & 0.249 \\
K2 (Diabetic control) & $166.17 \pm 4.17$ & $151.00 \pm 4.73$ & $-15.17 \pm 1.33$ & $0.026^{*}$ \\
K3 (Diabetic + Pioglitazone) & $166.17 \pm 10.87$ & $173.67 \pm 15.82$ & $12.50 \pm 21.57$ & 0.173 \\
P1 (Diabetic + Kefir with 1\% spirulina) & $170.67 \pm 17.69$ & $172.17 \pm 7.88$ & $1,50 \pm 23.85$ & 0.462 \\
P2 (Diabetic + Kefir with 2\% spirulina) & $188.67 \pm 32.44$ & $198.67 \pm 24.24$ & $10.00 \pm 37.54$ & 0.893 \\
\multicolumn{2}{c}{$p^{a}$} & $0.023^{*}$ & $0.001^{*}$ & 0.066 \\
\hline
\end{tabular}

Note: ${ }^{a}$ Wilcoxon; ${ }^{b}$ Kruskal-Wallis; ${ }^{*}$ Significant $(p<0.05)$.

Table 4 Fasting blood glucose levels (mg.dL $\left.{ }^{-1}\right)$.

\begin{tabular}{lllll}
\hline Group & \multicolumn{2}{l}{ Average fasting blood glucose \pm SD } & & $\boldsymbol{p}^{\boldsymbol{b}}$ \\
\cline { 2 - 5 } & Pre-treatment & Post-treatment & \multicolumn{2}{c}{ Delta pre-post } \\
\hline K1 (Normal control) & $69.37 \pm 1.25$ & $71.17 \pm 2.51$ & $1.80 \pm 1.91$ & 0.069 \\
K2 (Diabetic control) & $263.42 \pm 2.98$ & $265.53 \pm 2.43$ & $2.10 \pm 1.31$ & $0.011^{*}$ \\
K3 (Diabetic + Pioglitazone) & $268.05 \pm 3.27$ & $99.35 \pm 2.90$ & $-168.70 \pm 4.41$ & $0.000^{*}$ \\
P1 (Diabetic + Kefir with 1\% spirulina) & $270 \pm 3.03$ & $150.62 \pm 1.43$ & $-119.44 \pm 1.96$ & $0.000^{*}$ \\
P2 (Diabetic + Kefir with 2\% spirulina) & $266.98 \pm 4.36$ & $105.89 \pm 3.61$ & $-161.09 \pm 7.11$ & $0.000^{*}$ \\
$\boldsymbol{p}^{\boldsymbol{a}}$ & $0.000^{*}$ & $0.000^{*}$ & $0.000^{*}$ & \\
\hline
\end{tabular}

Note: ${ }^{a}$ One-Way ANOVA; ${ }^{b}$ Paired t-test; *Significant $(p<0.05)$.

Table 5 Postprandial blood glucose $\left(\mathrm{mg}^{\mathrm{d}} \mathrm{dL}^{-1}\right)$.

\begin{tabular}{lllll}
\hline Group & \multicolumn{2}{l}{ Average postprandial blood glucose \pm SD } & \multicolumn{2}{c}{$\boldsymbol{p}^{\boldsymbol{b}}$} \\
\cline { 2 - 5 } & Pre-treatment & Post-treatment & Delta pre-post & $0.000^{*}$ \\
\hline K1 (Normal control) & $77.92 \pm 1.80$ & $81.26 \pm 1.98$ & $3.34 \pm 0.97$ & $0.010^{*}$ \\
K2 (Diabetic control) & $278.58 \pm 3.25$ & $274.06 \pm 2.64$ & $-4.52 \pm 2.64$ & $0.000^{*}$ \\
K3 (Diabetic + Pioglitazone) & $281.38 \pm 3.74$ & $110.71 \pm 3.77$ & $-170.67 \pm 5.23$ & $0.000^{*}$ \\
P1 (Diabetic + Kefir with 1\% spirulina) & $283.52 \pm 1.74$ & $170.05 \pm 2.96$ & $-112.47 \pm 1.62$ & $0.000^{*}$ \\
P2 (Diabetic + Kefir with 2\% spirulina) & $280.24 \pm 4.36$ & $126.18 \pm 4.03$ & $-154.12 \pm 7.09$ & $0.000^{*}$ \\
$\boldsymbol{p}^{\boldsymbol{a}}$ & $0.000^{*}$ & $0.000^{*}$ & & \\
\hline
\end{tabular}

Note: ${ }^{a}$ One-Way ANOVA; ${ }^{b}$ Paired t-test; ${ }^{*}$ Significant $(p<0.05)$.

Table 6 SOD Activity (U.mL $\left.{ }^{-1}\right)$.

\begin{tabular}{lllll}
\hline Group & \multicolumn{2}{l}{ Average SOD activity \pm SD } & \multicolumn{2}{c}{$\boldsymbol{p}^{\boldsymbol{b}}$} \\
\cline { 2 - 5 } & Pre-treatment & Post-treatment & Delta pre-post \\
\hline K1 (Normal control) & $84.89 \pm 3.37$ & $83.60 \pm 3.87$ & $-1.29 \pm 1.36$ & 0.068 \\
K2 (Diabetic control) & $18.61 \pm 2.45$ & $25.00 \pm 3.09$ & $6.39 \pm 4.99$ & $0.026^{*}$ \\
K3 (Diabetic + Pioglitazone) & $24.48 \pm 4.26$ & $72.95 \pm 3.06$ & $48.47 \pm 5.63$ & $0.000^{*}$ \\
P1 (Diabetic + Kefir with 1\% spirulina) & $25.00 \pm 5.32$ & $50.82 \pm 3.74$ & $25.81 \pm 5.93$ & $0.000^{*}$ \\
P2 (Diabetic + Kefir with 2\% spirulina) & $23.43 \pm 4.07$ & $65.30 \pm 4.06$ & $41.86 \pm 6.82$ & $0.000^{*}$ \\
$\boldsymbol{p}^{\boldsymbol{a}}$ & $0.000^{*}$ & $0.000^{*}$ & $0.000^{*}$ & \\
\hline
\end{tabular}

Note: ${ }^{a}$ One-Way ANOVA; ${ }^{b}$ Paired t-test; ${ }^{*}$ Significant $(p<0.05)$. 


\section{Ethanol content}

One of the main products of kefir fermentation was ethanol. The kefir-spirulina prepared in this study has a relatively low ethanol content (Table 2), which was $0.59 \%$ (formula A) and $0.65 \%$ (formula B). Ethanol in the kefir is usually in the range of $0.5-2.0 \%$ (Rosa et al., 2017; Karaçalı, Özdemİr and Çon, 2018). Foods or beverages with low ethanol content are beneficial, especially in a country with religious restrictions regarding foods and beverages containing alcohol. The lactose fermentation of kefir generated ethanol, which contributed to the kefir's characteristic aroma (Ertekin and GuzelSeydim, 2010). Generally, the level of ethanol in kefir is influenced by yeast metabolism and heterofermentative bacteria that produce ethanol (Farnworth, 2008).

\section{Antioxidant activity}

The antioxidant activity of kefir-spirulina in this study was determined based on DPPH radical scavenging activity and presented as half-maximal inhibitory concentration $\mathrm{IC}_{50}$. The average total antioxidant activity of kefir-spirulina showed relatively strong activity, with $\mathrm{IC}_{50}$ of $43.65 \mathrm{ppm}$ and $42.00 \mathrm{ppm}$, for formulas $\mathrm{A}$ and $\mathrm{B}$, respectively (Table 2). An antioxidant is considered to be very strong if the $\mathrm{IC}_{50}$ is less than $50 \mathrm{ppm}$, strong if $\mathrm{IC}_{50}$ is $50 \mathrm{ppm}-100 \mathrm{ppm}$, weak if $\mathrm{IC}_{50}$ is $150 \mathrm{ppm}-200 \mathrm{ppm}$, and very weak if $\mathrm{IC}_{50}$ is more than $200 \mathrm{ppm}$ (Molyneux, 2004; Badarinath et al., 2010).

Kefir has been known to contain various antioxidant compounds capable of binding free radicals, decreasing the malondialdehyde concentration, and increasing glutathione peroxidase, thus regulating the level of oxidative stress (Rosa et al., 2017). Antioxidant activity in kefir-spirulina increased during the fermentation process. The proton of the acids produced by lactic acid bacteria during fermentation can be donated to the free radicals, increasing the primary antioxidant capacity (Waris and Ahsan, 2006).

\section{Bodyweight of experimental rats}

The rats' body weight during the whole experiment (before and after treatment) is shown in Table 3. After 7 days of acclimatization, all rats except for the normal control (K1) were induced by STZ-NA. After 3 days, all diabetic rats received treatments for 28 days, except for the negative control (K2). Rats in diabetic control groups (K2) experienced a decrease in their body weight $(p<0.05)$. This result is not surprising since STZ-NA induction may cause physiological changes and alteration in energy metabolism, affecting body weight. STZ induction may damage the pancreas. The pancreas' function is to synthesize and secrete insulin, which is vital in glucose utilization and, eventually, energy production. A disruption in insulin production causes a disturbance in energy homeostasis. As compensation, the body will shift towards fat and protein metabolism and may cause weight loss (Szkudelski, 2001). When diabetic rats were treated with the diabetic drug (K3) or kefir-spirulina (P1 and P2), body weight was compensated. We found no significant body weight changes $(p>0.05)$ in diabetic rats treated with kefir-spirulina (P1 and P2) or with diabetic drugs (K3). Kefir has an immunomodulatory effect capable of improving intestinal microflora and absorption, therefore improving body weight (Judiono, Djokomoeljanto and Hadisaputro, 2010).

\section{Fasting and postprandial glucose analysis}

Table 4 compares the changes in fasting plasma glucose levels in the five groups. The rats' blood glucose level in the normal control (K1) remained relatively stable at a normal level. In contrast, diabetic rats with no treatment (K2) suffered from consistently high glucose levels. The effect of 28 days of administration of kefir-spirulina (P1and P2) or the diabetic drug pioglitazone (K3) on the diabetic rats significantly decreased the glucose level $(p<0.001)$. Pioglitazone reduced blood glucose by improving glucose uptake in peripheral tissue and eventually enhanced insulin sensitivity (Waugh et al., 2006). On the other hand, kefir's ability to control plasma glucose levels has been shown through several studies (Nurliyani, Harmayani and Sunarti, 2015; BellikciKoyu et al., 2019). Kefir contains bioactive components such as peptides, short-chain fatty acids (SCFA), and exopolysaccharides (EPSs) that could affect the plasma glucose level. EPSs can increase cAMP concentration on Langerhans' islands so that the pancreas can increase insulin secretion (Al-Shemmari, Kassim Altaee and Hassan, 2018). It also activates glucagon-like peptide 1 (GLP 1) and gastric inhibitory peptide (GIP), which subsequently enhances insulin secretion (Al-Shemmari, Kassim Altaee and Hassan, 2018; Hadisaputro et al., 2012; Judiono, Djokomoeljanto and Hadisaputro, 2011; El-Bashiti, Zabut and Abu Safia, 2019). Furthermore, EPSs have also been proved to have antioxidant properties through free radical scavenging activity (Mao et al., 2014), which gives protection from oxidative damage that occurred on pancreatic cells. The high protein content in the kefir has an indirect role in regulating glucose levels through the regeneration and maintenance of pancreatic $\beta$ cells (Hulston, Churnside and Venables, 2015). SCFAs, on the other hand, are produced by the activities of probiotic microorganisms present in the kefir grain (Simova et al., 2002). SCFA were thought capable of protecting pancreatic $\beta$-cells, increasing enzymatic antioxidant activity, and improving insulin resistance through regulating the expression of tumor necrosis factor-alpha (alpha $\mathrm{TNF} \alpha$ ) and nuclear factor-kappa B (NF-kB) (Wang et al., 2017).

As expected, combining spirulina and kefir improved the ability to control glucose levels. Increasing the spirulina composition by a factor of two (formula B on group P2) improved the ability of kefir-spirulina to lower the glucose level (glucose changes of P1 vs P2 were $112.47 \mathrm{mg} . \mathrm{dL}^{-1}$ vs $154.12 \mathrm{mg} . \mathrm{dL}^{-1}$; post-hoc test $(p<0.05)$. This result indicated the synergistic effect of bioactive compounds present in the kefir-spirulina formulation. The synergistic effect of modified kefir has also been shown in several other studies (Nurliyani, Harmayani and Sunarti, 2015; Judiono, Djokomoeljanto and Hadisaputro, 2011). Spirulina consists of several bioactive compounds such as phycocyanin, carotenoids, vitamin E, chlorophyll, flavonoids, saponins, and phenolic compounds (Okechukwu et al., 2019). The C-phycocyanin (C-PC) peptide activates the insulin signaling pathway, regulates 
glucokinase expression in the pancreas and liver, and protects pancreatic $\beta$ cells (Li et al., 2020). Previous studies showed that spirulina consumption could reduce blood glucose levels (Huang et al., 2018; Aissaoui et al., 2017; Jarouliya et al., 2015). Spirulina reduced blood glucose levels by stimulating $\beta$ cell activity and increasing glucose transport to peripheral tissues (Layam and Reddy, 2007). Moreover, it has high fiber content, which slows down macronutrients' digestive process (Hernández-Alonso et al., 2017), thus maintaining the plasma glucose level.

We also analyzed postprandial glucose levels. Compared with fasting glucose, postprandial glucose level was thought to be better associated with the risk factor of diabetes and the level of HbAlc (Haddadinezhad and Ghazaleh, 2010), which reflects the glycemic control in diabetes patients over a certain period. According to the American Diabetes Association (ADA), the recommended postprandial glucose level for diabetes patients is below $180 \mathrm{mg} \cdot \mathrm{dL}^{-1}$ (ADA, 2018). The postprandial glucose levels of the five groups are presented in Table 5. In general, the changes in postprandial glucose of all groups are in agreement with the results obtained in fasting glucose levels. As can be seen in Table 5, treatment with pioglitazone (K3) and kefir-spirulina (P1 and P2) successfully reduced $(p<0.001)$ the postprandial glucose concentration to less than $180 \mathrm{mg} \cdot \mathrm{dL}^{-1}\left(\mathrm{~K} 3=110 \mathrm{mg} \cdot \mathrm{dL}^{-1}\right.$, $\mathrm{P} 1=170 \mathrm{mg} \cdot \mathrm{dL}^{-1}$, and $\left.\mathrm{P} 2=126 \mathrm{mg} \cdot \mathrm{dL}^{-1}\right)$. The ability of kefir to reduce postprandial glucose has also been shown in other studies (Alsayadi et al., 2014). The biggest changes in postprandial glucose levels in this study were observed in group P2, which was treated with kefir combined with $2 \%$ spirulina (formula $\mathrm{B}$ ).

\section{SOD Activity}

Table 6 shows the changes in the SOD activity of the experimental groups. Administration of kefir-spirulina in groups P1 and P2 significantly increased SOD levels $(p<0.001)$. The increase in SOD activity was 48.47 U.mL1, $41.86 \mathrm{U} \cdot \mathrm{mL}^{-1}$, and $25.86 \mathrm{U} \cdot \mathrm{mL}^{-1}$ for groups $\mathrm{K} 3, \mathrm{P} 2$, and $\mathrm{P} 1$, respectively. There is some background increase (6.39 U.mL ${ }^{-1}$ ) in the negative control group (K2), while the normal control group (K1) showed a relatively constant SOD activity $(p>0.05)$. A study by Omayma et al. (2013) showed that fermented soy could normalize the SOD and glutathione peroxidase (GPx) activities in rat tumor tissue. Kefir has a better ability to donate protons than nonfermented milk. Therefore, kefir can give protection against free radicals and thus increase SOD activity (Niccolai et al., 2019; Bellikci-Koyu et al., 2019; Zhang, Wu and Fei, 2016).

Oxidative stress is closely related to various diseases, including diabetes. The body will naturally develop enzymatic and nonenzymatic antioxidant defenses to balance oxidative stress. However, this endogenous protection might fail to prevent the overpopulated free radicals that are generated as the disease progresses. Therefore, exogenous antioxidant-rich foods such as kefir and spirulina are beneficial to back up the role of endogenous antioxidant systems.

\section{CONCLUSION}

The present study has demonstrated that kefir-spirulina showed high nutrient content, strong antioxidant capacity, relatively low alcohol concentration, and an ability to control glycemic status and SOD activity of a diabetic rat model. Based on the properties exhibited by kefir-spirulina in this study, kefir-spirulina has the potential for use in the dietary approach to the management of diabetes.

\section{REFERENCES}

ADA. 2018. Glycemic Targets: Standards of Medical Care in Diabetes-2018. Diabetes Care, vol. 41, p. S55-S64. https://doi.org/10.2337/dc18-S006

Afifah, D. N., Rahma, A., Nuryandari, S. S., Alviche, L., Hartono, P. I., Kurniawati, D. M., Wijayanti, H. S., Fitranti, D. Y., Purwanti, R. 2019. Nutrition Content, Protein Quality, and Antioxidant Activity of Varius Tempeh Gembus Preparations. Journal of Food and Nutrition Research, vol. 7, no. 8, p. 605-612. https://doi.org/10.12691/jfnr-7-8-8

Aissaoui, O., Amiali, M., Bouzid, N., Belkacemi, K., Bitam, A. 2017. Effect of Spirulina platensis ingestion on the abnormal biochemical and oxidative stress parameters in the pancreas and liver of alloxan-induced diabetic rats. Pharmaceutical Biology, vol. 55, no. 1, p. 1304-1312. https://doi.org/10.1080/13880209.2017.1300820

Alsayadi, M., Jawfi, Y. A., Belarbi, M., Soualem-Mami, Z., Merzouk, H., Sari, D. C., Sabri, F., Ghalim, M. 2014. Evaluation of Anti-Hyperglycemic and Anti-Hyperlipidemic Activities of Water Kefir as Probiotic on StreptozotocinInduced Diabetic Wistar Rats. Journal of Diabetes Mellitus, vol. 4, no. 2, 2 p. 85-95. https://doi.org/10.4236/jdm.2014.42015

Al-Shemmari, I. G. M., Kassim Altaee, R. A. M., Hassan, A. H. 2018. Evaluation of antidiabetic and antihyperlipidemic activity of kefir in alloxan induced diabetes mellitus rat. Scientific Journal Of Medical Research, vol. 2, no. 6, p. 8386. https://doi.org/10.37623/SJMR.2018.2606

AOAC. 2005. Association of Official Analytical Chemists. Arlington, Virginia, USA: Association of Official Analytical Chemists, Inc., Method Number 1, p. 24-56.

Arslan, S. 2014. A review: chemical, microbiological and nutritional characteristics of kefir. CyTA - Journal of Food, vol. 13, no. 3, p. 340-345. https://doi.org/10.1080/19476337.2014.981588

Badarinath, A. V., Rao, K. M., Chetty, C. M. S., Ramkanth, S., Rajan, T. V. S., Gnanaprakash, K. 2010. A Review on Invitro Antioxidant Methods: Comparisons, Correlations, and Considerations. International Journal of PharmTech Research, vol. 2, no. 2, p. 1276-1285.

Barengolts, E., Smith, E. D., Reutrakul, S., Tonucci, L., Anothaisintawee, T. 2019. The Effect of Probiotic Yogurt on Glycemic Control in Type 2 Diabetes or Obesity: A MetaAnalysis of Nine Randomized Controlled Trials. Nutrients, vol. 11, no. 3, 18 p. https://doi.org/10.3390/nu11030671

Bellikci-Koyu, E., Sarer-Yurekli, B. P., Akyon, Y., AydinKose, F., Karagozlu, C., Ozgen, A. G., Brinkmann, A., Nitsche, A., Ergunay, K., Yilmaz, E., Buyuktuncer, Z. 2019. Effects of Regular Kefir Consumption on Gut Microbiota in Patients with Metabolic Syndrome: A Parallel-Group, Randomized, Controlled Study. Nutrients, vol. 11, no. 9, 23 p. https://doi.org/10.3390/nu11092089

Catalá, A. 2009. Lipid peroxidation of membrane phospholipids generates hydroxy-alkenals and oxidized phospholipids active in physiological and/or pathological 
conditions. Chemistry and Physics of Lipids, vol. 157, no. 1, p. 1-11. https://doi.org/10.1016/j.chemphyslip.2008.09.004

Chandalia, M., Garg, A., Lutjohann, D., von Bergmann, K., Grundy, S. M., Brinkley, L. J. 2000. Beneficial Effects of High Dietary Fiber Intake in Patients with Type 2 Diabetes Mellitus. The New England Journal of Medicine, p. 13921398. https://doi.org/10.1056/NEJM200005113421903

Cho, N. H., Shaw, J. E., Karuranga, S., Huang, Y., de Rocha Fernandes, J. D., Ohlrogge, A. W., Malanda, B. 2018. IDF Diabetes Atlas: Global Estimates of Diabetes Prevalence for 2017 and Projections for 2045. Diabetes Research and Clinical Practice, vol. 138, p. 271-281. https://doi.org/10.1016/j.diabres.2018.02.023

Dias, G. P., dos Santos, R. C., Carvalho, R. C., de Souza, C. G., dos Santos, A. P. F., de Andrade, D. F., d'Avila, L. A. 2020. Determination of Methanol in Gasoline and Ethanol Fuels by High-Performance Liquid Chromatography. Journal of the Brazilian Chemical Society, vol. 31, no. 5, p. 10551063. https://doi.org/10.21577/0103-5053.20190272

El-Bashiti, T. A., Zabut, B. M., Abu Safia, F. F. 2019. Effect of Probiotic Fermented Milk (Kefir) on Some Blood Biochemical Parameters Among Newly Diagnosed Type 2 Diabetic Adult Males in Gaza Governorate. Current Research in Nutrition and Food Science, vol. 7, no. 2, p. 568-575. https://doi.org/10.12944/CRNFSJ.7.2.25

Ertekin, B., Guzel-Seydim, Z. B. 2010. Effect of fat replacers on kefir quality. Journal of the. Science of Food and Agriculture, vol. 90, no. 4, p. 543-548. https://doi.org/10.1002/jsfa.3855

FAO. 2010. Codex Standard for Fermented Milks. CODEX STAN 243-2003.p. 1-11.

Farnworth, E. R. 2008. Handbook of fermented functional foods. $2^{\text {nd }}$ ed. Boca Raton, USA : CRC Press. 600 p. ISBN 9780429136672. https://doi.org/10.1201/9781420053289

Gedawy, A., Martinez, J., Al-Salami, H., Dass, C. R. 2018. Oral insulin delivery: existing barriers and current counterstrategies. Journal of Pharmacy and Pharmacoly, vol. 70, no. 2, p. 197-213. https://doi.org/10.1111/jphp.12852

Habib, M. A. B., Parvin, M. 2008. A Review on culture, production, and use of spirulina as food for humans and feeds for domestic animals and fish. FAO Fisheries and Aquaculture Circular. Food and Agriculture Organization of the United Nations, Rome 2008. 33 p.

Haddadinezhad, S., Ghazaleh, N. 2010. Relation of fasting and postprandial and plasma glucose with hemoglobinA1c in diabetics. International Journal of Diabetes in Developing Countries, vol. 30, no. 1, p. 8-10. https://doi.org/10.4103/0973-3930.60002

Hadisaputro, S., Djokomoeljanto, R. R. J., Judiono, Soesatyo, M. H. 2012. The effects of oral plain kefir supplementation on proinflammatory cytokine properties of the hyperglycemia Wistar rats induced by streptozotocin. Acta Medica Indonesiana, vol. 44, no. 2, p. 100-104.

Hendel, N., Larous, L., Belbey, L. 2016. Antioxidant activity of rosemary (Rosmarinus officinalis L.) and its in vitro inhibitory effect on Penicillium digitatum. International Food Research Journal, vol. 23, no. 4, p. 1725-1732.

Hernández-Alonso, P., Camacho-Barcia, L., Bulló, M., Salas-Salvadó, J. 2017. Nuts and Dried Fruits: An Update of Their Beneficial Effects on Type 2 Diabetes. Nutrients, vol. 9, no. 7, 34 p.https://doi.org/10.3390/nu9070673

Huang, H., Liao, D., Pu, R., Cui, Y. 2018. Quantifying the effects of spirulina supplementation on plasma lipid and glucose concentrations, body weight, and blood pressure. Diabetes, Metabolic Syndrome and Obesity, vol. 11, p. 729742. https://doi.org/10.2147/DMSO.S185672
Hulston, C. J., Churnside, A. A., Venables, M. C. 2015. Probiotic supplementation prevents high-fat, overfeedinginduced insulin resistance in human subjects. British Journal of Nutrition, vol. 113, no. 4, p. 596-602. https://doi.org/10.1017/S0007114514004097

IBM. 2016. IBM SPSS Advanced Statistics 24. Armonk, NY: IBM Corp.

Jarouliya, U., Zacharia, A., Keservani, R. K., Prasad, G. B. K. S. 2015. Spirulina maxima and its effect on antioxidant activity in fructose induced oxidative stress with histopathological observations. Acta Facultatis Pharmaceuticae Universitatis Comenianae, vol. 62, no. 2, p. 13-19. https://doi.org/10.1515/afpuc-2015-0027

Judiono, Djokomoeljanto, Hadisaputro, S. 2011. Effects of clear probiotics on glycemic status, lipid peroxidation, antioxidative properties of streptozotocin induced hyperglycemia Wistar rats. Gizi Indonesia, vol. 34, no. 1, 6 p. https://doi.org/10.36457/gizindo.v34i1.95

Karaçalı, R., Özdemİr, N., Çon, A. H. 2018. Aromatic and functional aspects of kefir produced using soya milk and Bifidobacterium species. International Journal of Dairy Technology, vol. 71, no. 4, p. 921-933. https://doi.org/10.1111/1471-0307.12537

Koru, E. 2012. Earth Food Spirulina (Arthrospira): Production and Quality standards, Food Additive, Yehia ElSamragy, IntechOpen, p. 191-202. https://doi.org/10.5772/31848

Kýlýc, S., Uysal, H., Akbulut, N., Kavas, G., Kesenkes, H. 1999. Chemical, microbiological and sensory changes in ripening kefirs produced from starters and grains. Ege University Journal of Agricultural Faculty, vol. 36, p.111118.

Layam, A., Reddy, C. L. K. 2007. Antidiabetic property of spirulina. Diabetologia Croatica, vol. 35, no. 2, p. 29-33.

Li, Y., Aiello, G., Bollati, C., Bartolomei, M., Arnoldi, A., Lammi, C. 2020. Phycobiliproteins from Arthrospira Platensis (Spirulina): A New Source of Peptides with Dipeptidyl Peptidase-IV Inhibitory Activity. Nutrients, vol. 12, no. 3, 11 p. https://doi.org/10.3390/nu12030794

Magalhães, K. T., de Melo Pereira, G. V., Campos, C. R., Dragone, G., Schwan, R. F. 2011. Brazilian kefir: structure, microbial communities and chemical composition. Brazilian Journal of Microbiolog, vol. 42, no. 2, p. 693-702. https://doi.org/10.1590/S1517-83822011000200034

Mao, D. B., Shi, C. W., Wu, J. Y., Xu, C. P. 2014. Optimization of exopolysaccharide production in submerged culture of Daedalea dickinsii and its antioxidant activity. Bioprocess and Biosystems Engineering, vol. 37, p. 14011409. https://doi.org/10.1007/s00449-013-1111-3

Matough, F. A., Budin, S. B., Hamid, Z. A., Alwahaibi, N., Mohamed, J. 2012. The role of oxidative stress and antioxidants in diabetic complication. Sultan Qaboos University Medical Journal, vol. 12, no. 1, p. 556-569. hhttps://doi.org/10.12816/0003082

Molyneux, P. 2004. The use of the stable free radical Diphenylpicryl-hydrazyl (DPPH) for estimating antioxidant activity. Songklanakarin Journal of Science and Technology, vol. 26, no. 2, p. 211-219.

Moussa S. A. 2008. Oxidative stress in diabetes mellitus. Romanian Journal of Biophysics, vol. 18, no. 3, p. 225-236.

Niccolai, A., Shannon, E., Abu-Ghannam, N., Biondi, N., Rodolfi, L., Tredici, M. R. 2019. Lactic acid fermentation of Arthrospira platensis (spirulina) biomass for probiotic-based products. Journal of Applied Phycology, vol. 31, p. 10771083. https://doi.org/10.1007/s10811-018-1602-3 
Nurliyani, Harmayani, E., Sunarti. 2015. Antidiabetic Potential of Kefir Combination from Goat Milk and Soy Milk in Rats Induced with Streptozotocin-Nicotinamide. Korean Journal of Food Science of Animal Resources, vol. 35, no. 6, p. 847-858. https://doi.org/10.5851/kosfa.2015.35.6.847

Okechukwu, P. N., Ekeuku, S. O., Sharma, M., Nee, C. P., Chan, H. K., Mohamed, N., Froemming, G. R. A. 2019. In vivo and in vitro antidiabetic and antioxidant activity of spirulina. Pharmacognosy Magazine, vol. 15, no. 62, p. 1729.

Omayma, A. R., EL-Sonbaty, S. M., Aziza, S. A., Aboelftouh, A. E. 2013. Effect of Probiotic Fermented Soy Milk and Gamma Radiation on Nitrosourea-Induced Mammary Carcinogenesis. Nature and Science, vol. 11, no. 11, p. 35-42.

Otles, S., Cagindi, O. 2003. Kefir: A Probiotic Dairy Composition, Nutritional and Therapeutic Aspects. Pakistan Journal of Nutrition, vol. 2, no. 2, p. 54-59. https://doi.org/10.3923/pjn.2003.54.59

Plessas, S., Nouska, C., Mantzourani, I., Kourkoutas, Y., Alexopoulos, A., Bezirtzoglou, E. 2017. Microbiological Exploration of Different Types of Kefir Grains. Fermentation, vol. 3, no. $\quad 1, \quad 10 \quad$ p. https://doi.org/10.3390/fermentation3010001

Pogačić, T., Šinko, S., Zamberlin, Š., Samaržija, D. 2013. Microbiota of kefir grains. Mljekarstvo, vol. 63, no. 1, p. 314.

Rosa, D. D., Dias, M. M. S., Grześkowiak, Ł. M., Reis, S. A., Conceição, L. L., Peluzio, M. do C. G. 2017. Milk kefir: nutritional, microbiological and health benefits. Nutrition Research Reviews, vol. 30, no. 1, p. 82-96. https://doi.org/10.1017/S0954422416000275

Sadeghi, S., Jalili, H., Ranaei Sadat, S. O., Sadeghi, M. 2018. Anticancer and Antibacterial Properties in Peptide Fractions from Hydrolyzed Spirulina Protein. Journal of Agriculture, Science and Techology, vol. 20, p. 673-683.

Santaguida, P. L., Balion, C., Hunt, D., Morrison, K., Gerstein, H., Raina, P., Booker, L., Yazdi, H. 2005. Diagnosis, Prognosis, and Treatment of Impaired Glucose Tolerance and Impaired Fasting Glucose. AHRQ Evidence Reports/Technology Assessments, p. 1-11.

Sarkar, S. 2007. Potential of kefir as a dietetic beverage - A review. British Food Journal, vol. 109, no. 4, p. 280-290. https://doi.org/10.1108/00070700710736534

Schultz Johansen, J., Harris, A. K., Rychly, D. J., Ergul, A. 2005. Oxidative stress and the use of antioxidants in diabetes: Linking basic science to clinical practice. Cardiovascular Diabetology, vol. 4, 11 p. https://doi.org/10.1186/1475-2840$\underline{4-5}$

Senthil, N., Balu, P. M., Murugesan, K. 2013. Antihyperglycemic effect of spirulina, insulin and morinda citrifolia against streptozotocin induced diabetic rats. International Journal of Current Microbiology and Applied Sciences, vol. 2, no. 10, p. 237-559.

Simova, E., Beshkova, D., Angelov, A., Hristozova, T., Frengova, G., Spasov, Z. 2002. Lactic acid bacteria and yeasts in kefir grains and kefir made from them. Journal of Industrial Microbiology and Biotechnology, vol. 28, no. 1, p. 1-6. https://doi.org/10.1038/sj/jim/7000186

SOD Assay. 2019. KTv019. Kamiya Biomedical Company.

System, D. 2012. Glucose GOD FS: Application for serum and plasma. Application response.

Szkudelski, T. 2001. The mechanism of alloxan and streptozotocin action in B cells of the rat pancreas. Physiological Research, vol. 50, no. 6, p. 537-546.
Valko, M., Leibfritz, D., Moncol, J., Cronin, M. T. D., Mazur, M., Telser, J. 2007. Free radicals and antioxidants in normal physiological functions and human disease. The International Journal of Biochemistry and Cell Biology, vol. 39, no. 1, p. $44-84$. https://doi.org/10.1016/j.biocel.2006.07.001

Venkatakrishan, K., Chiu, H. F., Wang, C. K. 2019. Popular functional foods and herbs for the management of type-2diabetes mellitus: A comprehensive review with special reference to clinical trial and its proposed mechanism. Journal of Functional Foods, vol 57, p. 425-438. https://doi.org/10.1016/j.jff.2019.04.039

Wang, X., Juan, Q. F., He, Y. W., Zhuang, L., Fang, Y. Y., Wang, Y. H. 2017. Multiple effects of probiotics on different types of diabetes: a systematic review and meta-analysis of randomized, placebo-controlled trials. Journal of Pediatric Endocrinology and Metabolism, vol. 30, no. 6, p. 611-622. https://doi.org/10.1515/jpem-2016-0230

Waris, G., Ahsan, H. 2006. Reactive oxygen species: Role in the development of cancer and various chronic conditions. Journal of Carcinogenesis, vol. 5, no. 14, 8 p. https://doi.org/10.1186/1477-3163-5-14

Waris, G., Ahsan, H. 2006. Reactive oxygen species: Role in the development of cancer and various chronic conditions. Journal of Carcinogenesis, vol. 5, no. 14, 8 p. https://doi.org/10.1186/1477-3163-5-14

Waugh, J., Keating, G. M., Plosker, G. L., Easthope, S., Robinson, D. M. 2006. Pioglitazone: A Review of its Use in Type 2 Diabetes Mellitus. Drugs, vol. 66, p. 85-109. https://doi.org/10.2165/00003495-200666010-00005

WHO. 1999. Definition, diagnosis and classification of diabetes mellitus and its complications: report of a WHO consultation. Part 1, Diagnosis and classification of diabetes mellitus). Geneva, World Health Organization.

Wu, L. C., Ho, J. A. A., Shieh, M. C., Lu, I. W. 2005. Antioxidant and Antiproliferative Activities of Spirulina and Chlorella Water Extracts. Journal of Agricultural and Food Chemistry, vol. 53, no. 10, p. 4207-4212. https://doi.org/10.1021/jf0479517

Zhang, Q., Wu, Y., Fei, X. 2016. Effect of probiotics on glucose metabolism in patients with type 2 diabetes mellitus: A meta-analysis of randomized controlled trials. Medicina, vol. 52, no. $1, \quad$ p. $28-34$. https://doi.org/10.1016/j.medici.2015.11.008

\section{Acknowledgments:}

The authors thank Gemala Anjani, SP, M.Si, Ph.D., and Dr. Muflihatul Muniroh, M.Si., Med., MD at the Faculty of Medicine, Diponegoro University, for their valuable input. This research was supported by a grant from BKPPD and a regional public hospital of Cirebon West Java, Indonesia.

\section{Contact address:}

Nur Laela, Diponegoro University, Faculty of Medicine, Department of Nutrition Science, Jl. Prof. Soedarto S.H. 50275, Semarang, Indonesia, Tel.: +62 081324381073,

E-mail: nurela460@gmail.com

ORCID: https://orcid.org/0000-0002-1740-420X

Prof. Dr. Ir. Anang Mohamad Legowo, M.Sc., Ph.D. Diponegoro University, Faculty of Animal and Agricultural Sciences, Food Technology Department, Jl. Prof. Soedarto S.H 50275, Semarang, Indonesia, Tel.: +62 08156503627 ,

E-mail: anang_mL@yahoo.com

ORCID: https://orcid.org/0000-0002-5457-1111 
*Faizah Fulyani, S.Si, M.Sc, Ph.D., Diponegoro University, Faculty of Medicine, Department of Medical Biology and Biochemistry, Jl. Prof. Soedarto S.H 50275, Semarang, Indonesia, Tel.: +62 08112880027,

E-mail: f.fulyani@ffk.undip.ac.id

ORCID: https://orcid.org/0000-0003-3143-2941
Corresponding author: * 